\title{
Efficient Microwave-Assisted Solvent-Free Synthesis and Molecular Docking Studies of 2-pyridone derivatives as Anticancer Agents and Evaluation of Cytotoxic Effects
}

M.H.abdellattif ${ }^{1 *}$, I.A.Maghrabi ${ }^{2}$, M.M.H.Areef ${ }^{3}$, Hany A. EIDeab ${ }^{4}$ Samar M Mouneir ${ }^{5}$ and Amany Belal ${ }^{4},{ }^{6}$ 1-Deanship of scientific research Taif university, KSA, 2- Dean of Pharmacy College, Taif university, KSA, 3Chemistry Department, Faculty of science, Benha university, Egypt, 4- Pharmaceutical chemistry, Pharmacy

College, Taif university, KSA, 5- Department of Pharmacology,Faculty of Veterinary Medicine,Cairo University,12211,Egypt. 6-Medicinal chemistry department, faculty of pharmacy, Beni-Suef, Egypt, *magdah11uk@hotmail.com m.hasan@tu.edu.sa

Applied researches are conducted with financial support of the Deanship of scientific research, Taif University,

\section{Author contributions:}

KSA under the Subsidy Grant Agreement №.1-436-3855

1- Dr. Magda Abd ellattif had been prepared the laboratory and chemicals for synthesis; she collected the material science, made all the investigation and elucidation for all the synthetic compounds using $I R$, and $1 \mathrm{D}$, Finally she wrote the paper and published it.

2- Dr. Ibrahim Maghrabi, directed the routine work during funding of the project

3- Prof. Dr. Mohamed Hemli Arief revised the paper before publishing.

4- Dr. Hany EIDeab, helped in synthesis

5- Prof Dr. Samar Mounier for active participation in the pharmacological investigations

6- Dr. Amany Belal : performed and discussed molecular docking studies.

\section{Abstract}

Introduction: A green protocol will be used to synthesize a novel series of 3-cyano-5- arylazo-pyridones $\left(9_{\mathrm{a}-\mathrm{c}}\right)$ and $\left(10_{\text {di- }}\right)$.

Methodology: Structures of the new products will be confirmed on the basis of spectroscopic data (FT-IR, 1D, NMR) as well as alternative synthetic routes, anticancer cell-line will be investigated and also molecular docking studies will be applied.

Results: The activity against different cancer cell-line will be studied. Compounds with electron withdrawal group showed the highest activities.

\section{Introduction}

It was found that cancer is a fatal disease and it is the $2^{\text {nd }}$ one around the world after heart failure, Pyridone derivatives, pyridone nucleus containing compounds, and most of pyridine skeleton compounds are very important for researchers in chemistry as well as biology because large number of these compounds are found in nature, especially 2-pyridone ring system which imposes a great spectrum of biological activities as anticancer drugs, antibacterial, and antimicrobial, antituberculosis, and many other biological activities. ${ }^{1,2}$ In addition some of cyano derivatives of pyridone are used in manufacture of dyes ${ }^{3}$. Other isomers of 2-pyridone is 4-pyridone which has magnetic properties which can be used in synthesis of liquid crystals and has antioxidant properties which can be used as drug in hyperglycemia ${ }^{4}$

Guareschi-Thorpe described a general method by condensation of dicarbonyl compounds with cyanoacetamide ${ }^{5,6}$ which is about 3-2 type of condensation leads to formation of pyridone. ${ }^{7}$

In most of these approaches, variety of 2-pyridone derivatives has been synthesized through introducing different functional groups on the pyridone ring. Development of potent and effective anticancer drugs is one of the more pressing goals of current medicinal chemistry. ${ }^{8,9}$ Various nucleosides have been reported to have important biological properties. ${ }^{10}$ In particular, 4-Amino-3-fluoro-1-( $\beta$-D-ribofuranosyl)-2(1H)-pyridone 1 inhibits the growth of $\mathrm{HL}-60$ lymphoid leukemia cells with IC50 =1.07 x 10-5 M, while 2'-deoxy analogue of 1 is active against lymphoid leukemia L1210 cells. Also, the acetyl derivative of 1 exhibits similar albeit less potent activities than $1 .{ }^{11}$ Selective inhibitors for the human immunodeficiency virus type1 reverse transcriptase (HIV-RT) are derivatives of pyridine. For example, 3-(4',7'-Dimethyl benzoxazol-2'-yl)amino-5-ethyl-6-methyl pyridine-2(1H)-one 2 and its 4,7-dichloro analogue have been reported to inhibit the spread of HIV1 infection by $95 \%$ in MT4 cell culture and were selected for clinical trials as antiviral agents. 4-Benzylpyridone ${ }^{10}$ has been shown to possess potent HIV-1 specific reverse transcriptase inhibitor properties. ${ }^{12}$ (figure 1) 
<smiles>Nc1ccn(C2OC(CO)C(O)C(O)C2O)c(=O)c1F</smiles><smiles>CCc1cc(NCc2nc3c(C)ccc(C)c3o2)c(=O)[nH]c1C</smiles><smiles>CCc1c(C)[nH]c(=O)c(N)c1Cc1cc(C)cc(C)c1</smiles>

Figure 1: Some 2-pyridone derivatives have important biological properties.

In the last century, the heating techniques for organic processes have not changed much, during which the oil-bath and heating mantle have been the most common heating methods. Recently, microwave-enhanced organic synthesis methods have attracted a great attention. In addition, microwave heating devices are an environmentally friendly energy source due to the following reasons:

a) Their ability to rapidly heat reaction mixtures to produce the desired product with high selectivity,

b) The energy consumption is only a fraction of that used for classical heating,

c) With rapid heating to high temperatures under pressure, microwave irradiation permits a minimum amount of solvents of low boiling point to work efficiently, producing a minimum of byproducts. ${ }^{13-15}$

In organic chemistry, microwave technology has only been implemented since the mid-1980s because of the lack of controls and reproducibility and because of some safety aspects. ${ }^{16}$ In recent years, these difficulties have been overcome and many successful organic reactions with radically enhanced reaction rates have been performed.

In the electromagnetic spectrum, the microwave frequencies are located between infrared radiation and radio waves $(0.3-$ $300 \mathrm{GHz}$ ). In order to avoid interference with telecommunication and microwave radar, industrial and domestic microwave apparatuses are generally to the wavelength of $12.2 \mathrm{~cm}(2450 \mathrm{GHz})$ (Fig. 2). ${ }^{17}$ In the electromagnetic spectrum, the molecule vibrates in the infrared field and rotates in the microwave field as shown in Figure 2.

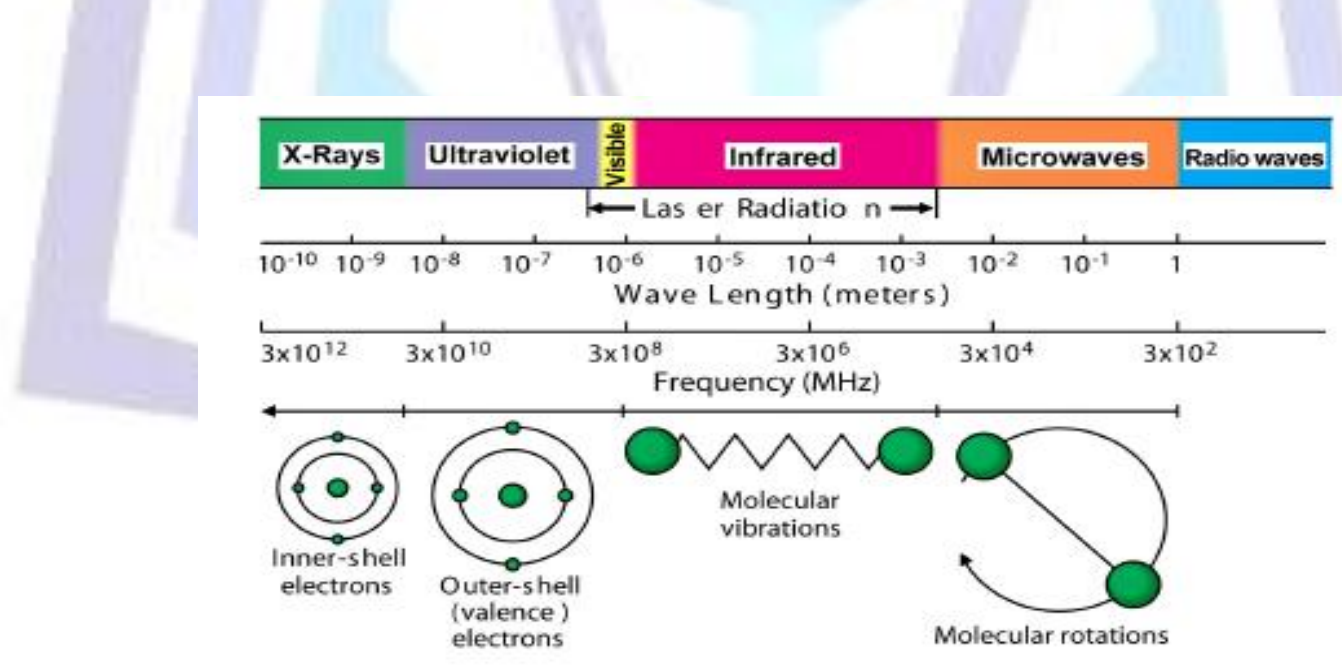

Figure (2)

\section{Heating Mechanisms}

The magnetron-tube generates wave power for microwave processing. The electric field component is responsible for the heating, which occurs by two main mechanisms (Fig. 3, A and B): ${ }^{19,20,21, \text { and } 22}$

\section{Dipolar polarization mechanism:}

The substance that possesses a dipole moment will align itself with an external electric field. When the field oscillates, it causes the dipole molecules to rotate. If the rotating frequency of the molecules is not high enough to follow the field 
frequency, because of molecular friction and collisions in a viscous liquid, there will be a phase difference and then energy will be lost producing dielectric heating (Fig. 3, A).

Conduction mechanism: The second major interaction occurs when a solution contains ions which oscillate in the solution under the influence of an electric field (Fig. 3, B). This kinetic energy will be converted to heat because of the increased collision rate. In addition, the rate of temperature increase is not only dependent on the dipolar polarization and conduction mechanisms but also on the emissivity, geometry and volume of the reaction mixture and the strength of the applied field. ${ }^{19}$

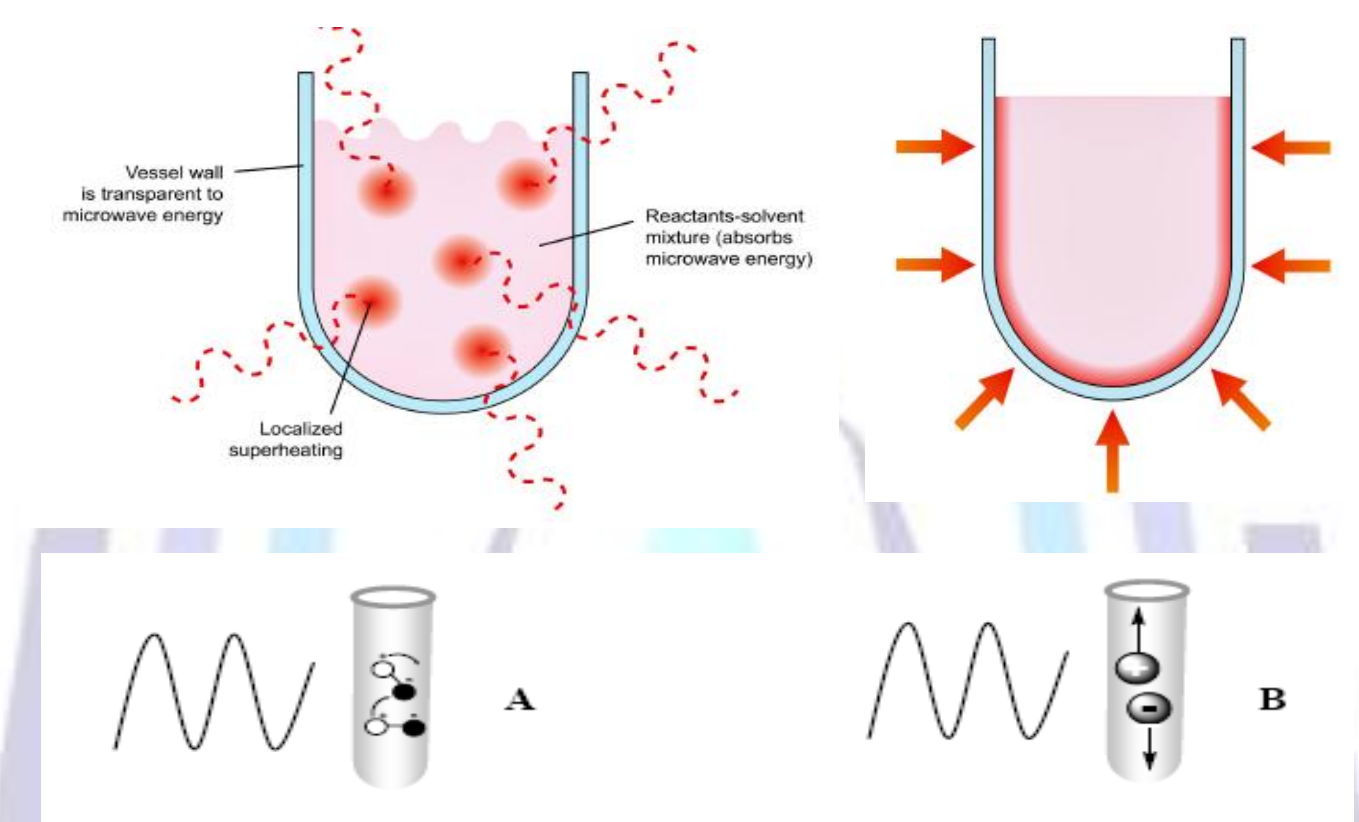

Figure (3) (A) Dipolar polarization mechanism, (B) Conduction mechanism.

\section{Microwave Equipments:}

\section{Multi-mode ovens}

Many microwave-promoted organic syntheses have so far been conducted in domestic microwave ovens. In household ovens, the microwaves are randomly distributed within the cavity. Reflection of the microwaves generates a three dimensional stationary pattern of standing waves, called modes. In these multi-mode domestic ovens, a randomly distributed field pattern will be formed with high and low field strengths, generally referred to as "hot and cold spots" (Fig. 4).
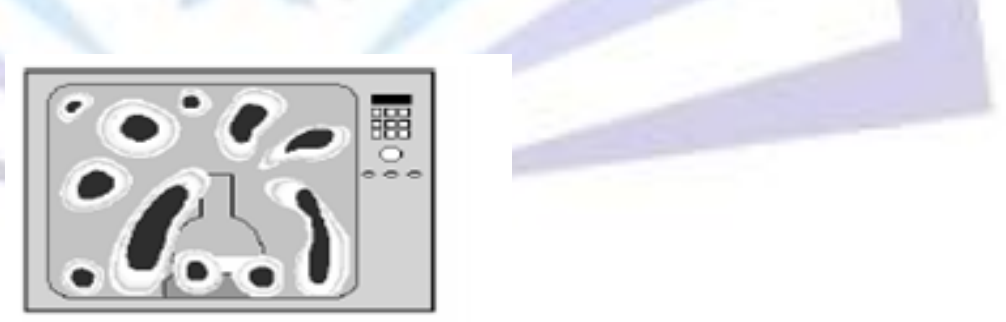

\section{Figure (4) Multi-mode oven.}

Therefore, when performing reactions in multi-mode ovens, there is a risk of getting poorly reproducible results because of the non-uniform heating and on and off cycles, especially if the temperature or pressure cannot be constantly monitored during the course of the reaction.

\section{Single-mode cavities}

In such mode, a continuous standing-wave is generated with well-defined regions of maximum and minimum field strengths. Consequently, a single-mode cavity delivers optimal reproducibility and energy efficiency, especially with an adequate temperature and pressure control system (Fig. 5). 

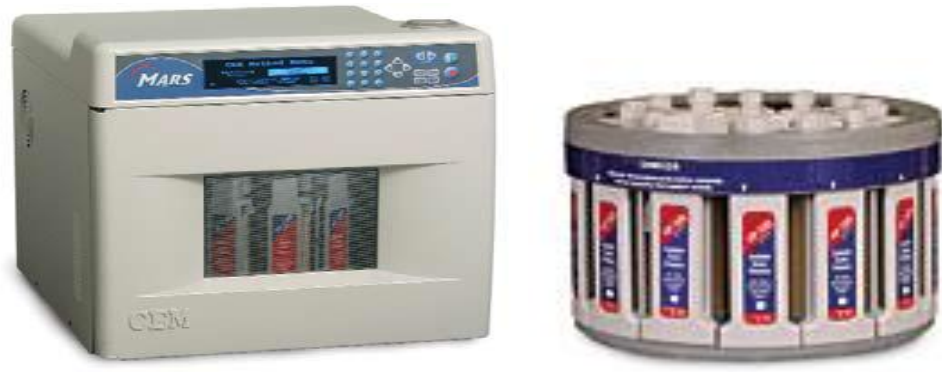

Figure (5) CEM Microwaves

The aims of our work are to synthesize some novel Polysubstituted-2-pyridones, to establish an easy direct method, to synthesize 2-Pyridone analogues, to study the mechanisms of these reactions, to confirm the obtained structures using different spectroscopic techniques, to study the biological activity of the obtained products, and to study the structural activity relationship.

\section{Results and Discussion}

\section{A-Chemistry}

\section{Synthesis of 3-cyano-4, 6-disubstituted-2-pyridones (9) under microwave irradiation without solvent and using a solid media.}

In microwave assisted organic synthesis the question is going to be whether the reaction should be carried out in a closed environment or at atmospheric pressure and using solvent or solvent less. The scale of the reaction will probably be the deciding factor. In present work, the pressurized conditions for the reactions were used. A pressurized environment can be very advantageous to many different kinds of chemistries. Solvents can be heated up to temperatures that are two to four times their respective boiling points. This characteristic condition of microwave synthesis provides a large rate enhancement. Also, pressurized reaction conditions also provide inert atmospheres for use of air and moisture sensitive reagents. Atmospheric reactions can be performed on a much larger scale than pressurized ones.

From synthetic point of view, in spite of enormous literature on the utility of 1,3-dicarbonyl compounds in heterocyclic synthesis a little attention has been paid to their utility under microwave irradiation in the chemical transformations including such class of compounds and their synthesis without using solvent. Generally, the pyridone derivative (9) was readily obtained by irradiating equimolar quantities of substited 1,3 propanedione (4a-c) and cyanoacetamide (6) using silica gel as reaction medium under pressurized microwave conditions (Scheme 1).

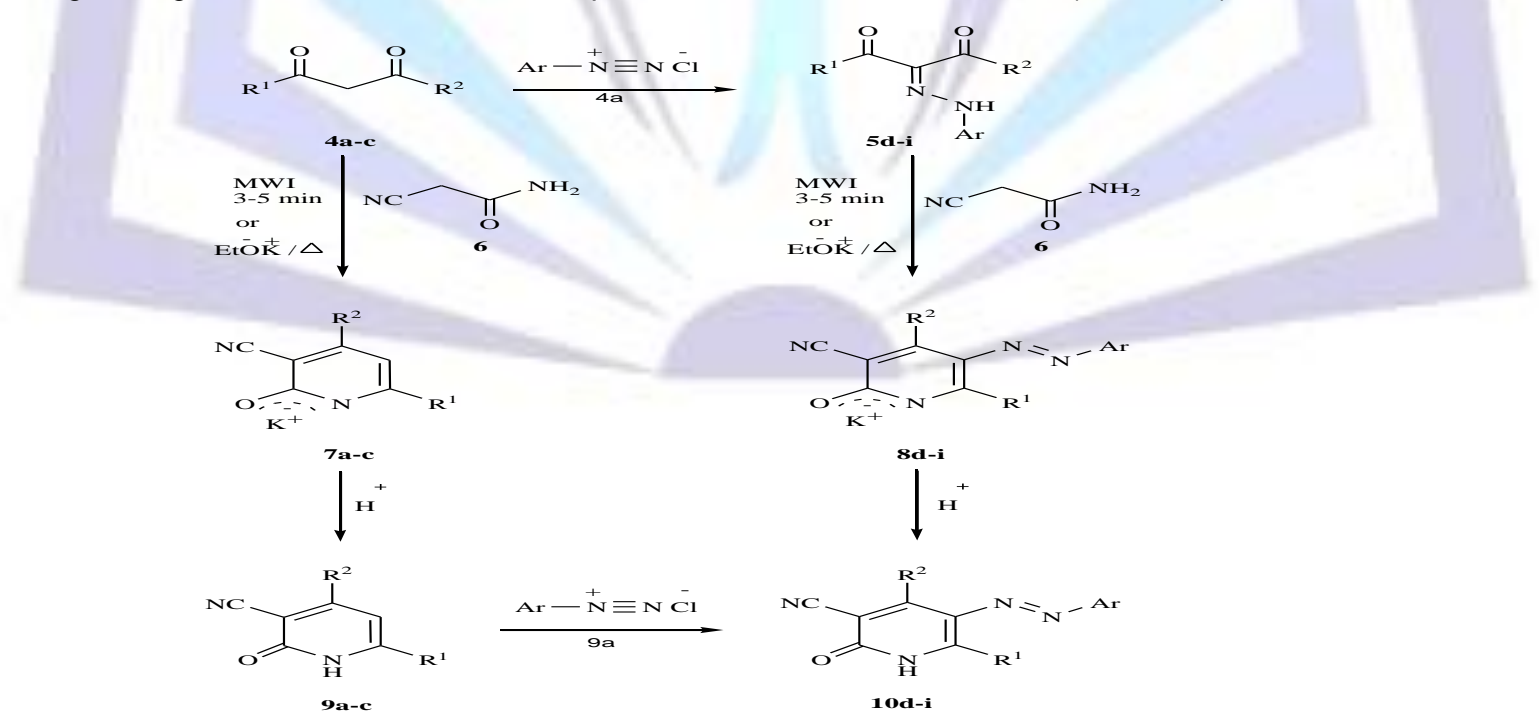

\section{Scheme 1}


Table (1) substituted 1,3propanedione (9) under microwave irradiation

\begin{tabular}{|cccc|}
\hline $\begin{array}{c}\text { Substituted } \\
\text { 1,3propanedione }\end{array}$ & $\mathrm{R}^{1}$ & $\mathrm{R}^{2}$ & Yield \% \\
\hline $9 \mathbf{a}$ & $-\mathrm{CH}_{3}$ & $-\mathrm{CH}_{3}$ & 70 \\
\hline $\mathbf{9 b}$ & $\mathrm{ph}-$ & $-\mathrm{CH}_{3}$ & 65 \\
\hline $9 \mathbf{c}$ & $\longleftarrow$ & $-\mathrm{CF}_{3}$ & 51 \\
\hline
\end{tabular}

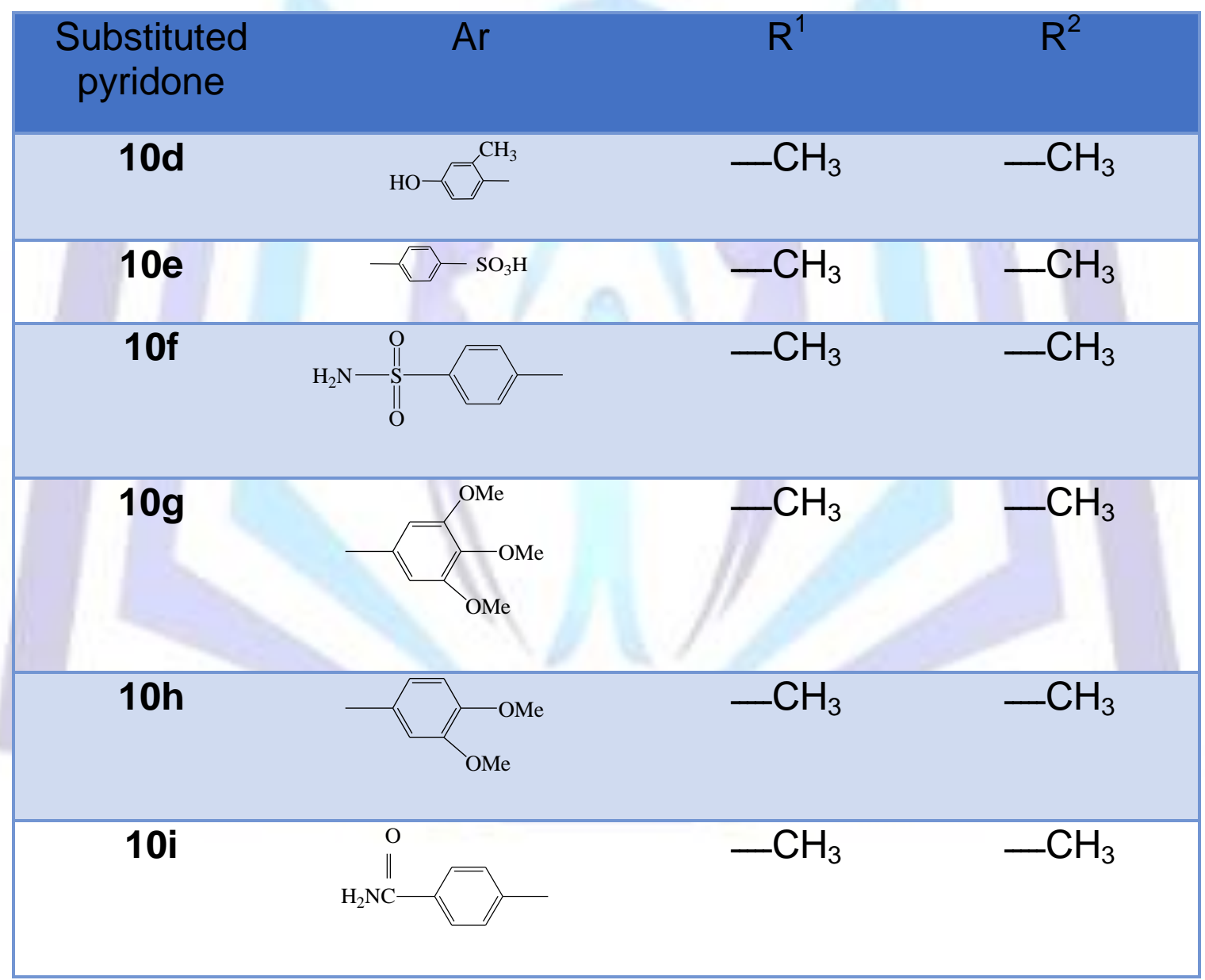

Table (2) substituted azo-pyridone 10(d-i)

In order to achieve the optimized conditions suitable for the reaction, microwave irradiations were performed under different conditions of solid media, temperature, time and power in order to achieve the optimized conditions suitable for the reaction to prepare the main product $(9 a)$

\section{Irradiation using different solid media}

Solution-phase reactions performed in the presence of solvent can be either homogeneous or heterogeneous. Microwave irradiation has been used extensively and successfully with homogeneous solution-phase reactions. These types of trans- 
formations are widely used and highly successful. On the other hand the use of solids as a reaction medium is one of the green techniques used in green synthesis with high safety.

The Type of the solid plays a significant role in microwave-assisted reactions. When different types of solid supports have been used as a media for such reaction, the reaction products were obtained in good to moderate yields (Table 1). Irradiating the reaction mixture without solvent using silica gel afforded the target pyridone in excellent yields (entry 3 , Table 3). On the other hand, the product was obtained in moderate yields when alumina was used (entry 2, Table 2) The results of the change of solid supports on the yield of reaction product under microwave irradiation was summarized in Table 3.

Table (3) Effect of the solvent

\begin{tabular}{|ccc|}
\hline Entry & $\begin{array}{c}\text { Solid } \\
\text { medium }^{\mathrm{a}}\end{array}$ & $\begin{array}{c}\text { Yield } \\
\%^{\mathrm{b}}\end{array}$ \\
\hline $\mathbf{1}$ & Alumina & 65 \\
\hline $\mathbf{2}$ & $\begin{array}{c}\text { Calcinated } \\
\text { Alumina }\end{array}$ & 70 \\
\hline $\mathbf{3}$ & Silica Gel & 86 \\
\hline $\mathbf{4}$ & $\begin{array}{c}\text { Polyethylene } \\
\text { glycol }\end{array}$ & 56 \\
\hline
\end{tabular}

a The reactions were carried out using $1600 \mathrm{~W}$ microwave power for $7 \mathrm{~min}$.

\section{i- Irradiation at different temperatures}

Next, the effect of temperature on the yield of reaction was investigated. The reaction was performed under different temperatures using the options of the CEM microwave machine. It was found that the best temperature for such kind of reactions is the $220^{\circ} \mathrm{C}$ however higher temperature afforded almost the same yield or lower by small extant but the reaction product could not be isolated in a pure state due to some decomposition occurred.

Table (4) Effect of Temperature

\begin{tabular}{|ccc|}
\hline Entry & Temperature & Yield ${ }^{\mathrm{b}}$ \\
\hline $\mathbf{1}$ & 60 & 19 \\
\hline $\mathbf{2}$ & 80 & 30 \\
\hline $\mathbf{3}$ & 90 & 35 \\
\hline $\mathbf{4}$ & 150 & 68 \\
\hline $\mathbf{5}$ & 150 & 80 \\
\hline $\mathbf{6}$ & 200 & 92 \\
\hline $\mathbf{7}$ & 220 & 88 \\
\hline $\mathbf{8}$ & 240 & 90 \\
\hline
\end{tabular}

\section{Irradiation for different times}

The effect of the time of irradiation have been also investigated. As the time of irradiation increases, as the yield of the product increases. However after $7 \mathrm{~min}$, the yield becomes constant. The maximum yield in such reaction was obtained after 7 minutes. Increasing the time to 10 min decreases the yield considerably due to decomposition. 


\begin{tabular}{|ccc|}
\hline Entry & ${\text { Irradiation time }(\mathbf{m i n})^{\mathrm{a}}}$ & ${\text { Yield }{ }^{\mathrm{b}}}^{\mathrm{b}}$ \\
\hline $\mathbf{1}$ & 1 & 0 \\
\hline $\mathbf{2}$ & 2 & 21 \\
\hline $\mathbf{3}$ & 3 & 32 \\
\hline $\mathbf{4}$ & 5 & 73 \\
\hline $\mathbf{5}$ & 7 & 88 \\
\hline $\mathbf{6}$ & 8 & 88 \\
\hline $\mathbf{7}$ & 10 & 65 \\
\hline
\end{tabular}

${ }^{a}$ The reactions were carried out using $1600 \mathrm{~W}$ microwave power at $220{ }^{\circ} \mathrm{C} .{ }^{\mathrm{b}}$ Isolated yields.

\section{ii- Irradiation using different powers}

The effect of different power of the microwaves was investigated and it was found that using $1600 \mathrm{~W}$ power was enough to afford a maximum yield of the reaction products.

Table (6) Effect of the microwave power

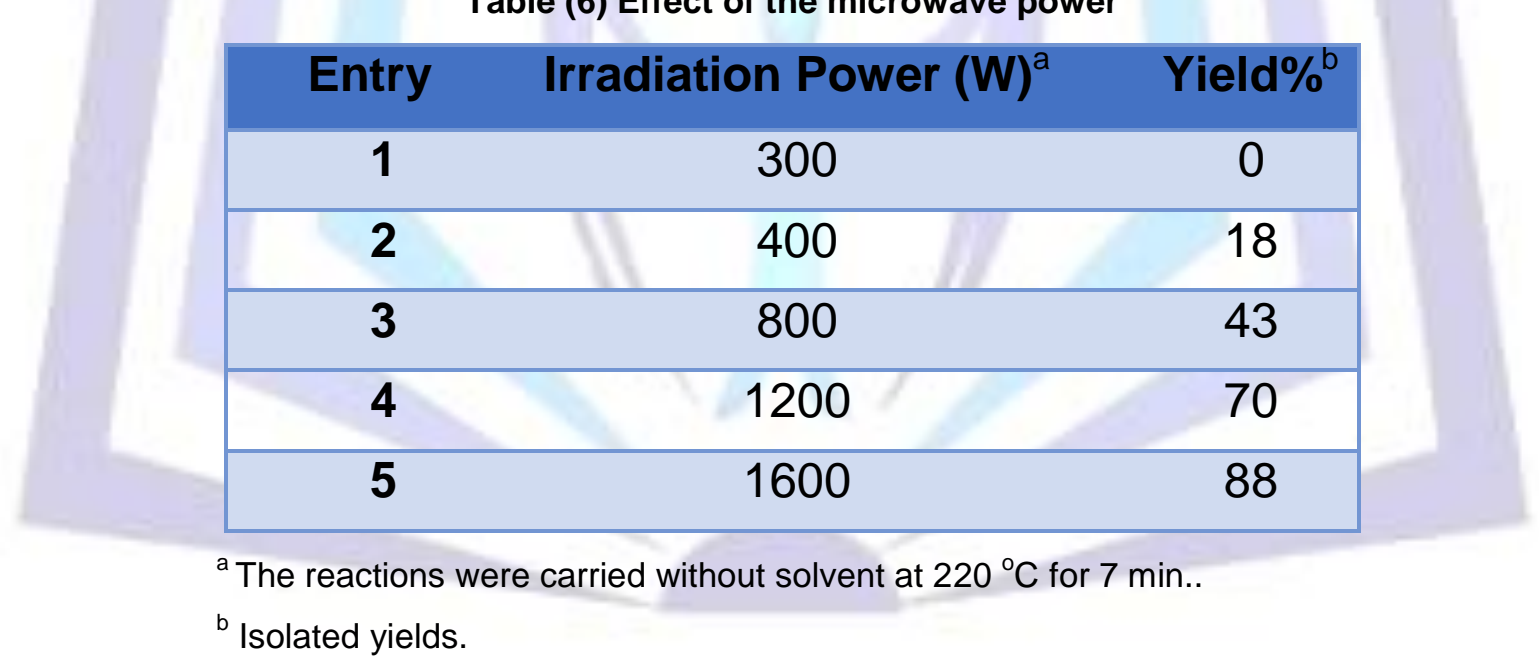

From the previous investigations, it was found that using solvent less $/ 1600 \mathrm{~W} / 220^{\circ} \mathrm{C} / 7 \mathrm{~min}$. conditions for such reaction gave the optimum yield of the pyridone $(9 a)$.

\section{B-Biology}

\section{Anticancer activity}

The newly synthesized compounds were tested for in vitro anticancer activity using SRB cytotoxicity assay method. The anticancer screening revealed that the synthesized compounds exhibited cytotoxic activity against MCF-7 Breast cancer cell lines and HEPG-2 Liver cancer cell lines in variable degrees.

Compound (10e) is more potent than (10d) compound on MCF-7 Breast cancer cells as its IC $50 \% 75.2 \mathrm{Ug} / \mathrm{ml} \mathrm{compared}$ to 98.57 for CRES compound. On the other side, compound (10d) has a potent anticancer activity IC50 (55.03 $\mathrm{Ug} / \mathrm{ml})$ on HEPG-2 cell lines compared to that of $(10 \mathrm{e})$ compound $(60.24 \mathrm{Ug} / \mathrm{ml})$.In this concern, El said et al $2012^{25}$ and $\mathrm{Lv}$ et.al., $2013^{26}$ reported that new 2 - pyridone derivatives showed potent anticancer activity against HEPG2 cell lines and 

arresting cells in the G0/G1 phase as previously determined by Salah et.al.,2015. ${ }^{27}$ by using flow cytometry.

Table (7) Test for anticancer

\section{MCF-7 Breast Cancer}

$10 d$

$\begin{array}{ccc}\text { Mean SD Viability } & \begin{array}{c}\mathrm{IC} 50 \% \\ \mathrm{Ug} / \mathrm{ml}\end{array}\end{array}$

\begin{tabular}{llllllll}
\hline 0 & 1.837 & 1.765 & 1.782 & 1.795 & 0.034 & 100 & 98.57
\end{tabular}

$\begin{array}{lllllll}6.25 & 1.675 & 1.654 & 1.627 & 1.652 & 0.022 & 92.05\end{array}$

$\begin{array}{lllllll}12.5 & 1.526 & 1.586 & 1.58 & 1,564 & 0.029 & 87.15\end{array}$

$\begin{array}{lllllll}25 & 1.489 & 1.497 & 1.503 & 1.496 & 0.006 & 83.38\end{array}$

$\begin{array}{lllllll}50 & 1.519 & 1.421 & 1.473 & 1.471 & 0.043 & 81.46\end{array}$

$\begin{array}{lllllll}100 & 0.743 & 0.814 & 0.780 & 0.779 & 0.031 & 43.41\end{array}$

\begin{tabular}{|c|c|c|c|c|c|c|c|}
\hline $10 e$ & & & & Mean & SD & Viability & IC50\% \\
\hline 0 & 1.906 & 1.883 & 1.806 & 1.865 & 0.046 & 100 & 75.2 \\
\hline 6.25 & 1.549 & 1.699 & 1.53 & 1.609 & 0.676 & 86.29 & \\
\hline 12.5 & 1.511 & 1.506 & 1.501 & 1.506 & 0.004 & 80.75 & \\
\hline 25 & 1.553 & 1.376 & 1.399 & 1.442 & 0.086 & 77.35 & \\
\hline
\end{tabular}




\begin{tabular}{|c|c|c|c|c|c|c|c|}
\hline 50 & 1.385 & 1.345 & 1.408 & 1.379 & 0.028 & 73.96 & \\
\hline 100 & 1.476 & 0.766 & 0.579 & 0.613 & 0.130 & 32.87 & \\
\hline \multicolumn{8}{|c|}{$\begin{array}{c}\text { HEP G-11 (Hepatocytes cancer } \\
\text { cell line) }\end{array}$} \\
\hline $10 d$ & & & & Mean & SD & Viability & $\begin{array}{l}\mathrm{IC} 50 \% \\
\mathrm{Ug} / \mathrm{ml}\end{array}$ \\
\hline 0 & 0.558 & 0.509 & 0.580 & 0.549 & 0.032 & 100 & 55.03 \\
\hline 6.25 & 0.524 & 0.402 & 0.364 & 0.430 & 0.075 & 78.32 & \\
\hline 12.5 & 0.440 & 0.424 & 0,406 & 0.423 & 0.015 & 77.11 & \\
\hline 25 & 0.399 & 0.383 & 0.357 & 0.379 & 0.019 & 69.16 & \\
\hline 50 & 0.349 & 0.396 & 0.316 & 0.354 & 0.036 & 64.42 & \\
\hline 100 & 0.059 & 0.324 & 0.052 & 0.145 & 0.139 & 26.41 & \\
\hline $10 e$ & & & & Mean & SD & Viability & IC50\% \\
\hline 0 & 0.152 & 1.145 & 0.162 & 1.153 & 0.007 & 100 & 60.24 \\
\hline 6.25 & 0.095 & 1.122 & 0.105 & 0.107 & 0.0122 & 70.15 & \\
\hline 12.5 & 0.113 & 0.063 & 0.138 & 0.104 & 0.0341 & 68.41 & \\
\hline 25 & 0.075 & 0.088 & 0.124 & 0.096 & 0.0227 & 62.53 & \\
\hline 50 & 0.08 & 0.078 & 0.089 & 0.082 & 0.0052 & 53.81 & \\
\hline 100 & 0.06 & 0.063 & 0.067 & 0.063 & 0.0031 & 41.39 & \\
\hline
\end{tabular}

\section{Molecular Docking}


vascular endothelial growth factor receptor 2 (VEGFR-2) is is an important protein involved in angiogenesis process, compounds that can bind and inhibit these kinases will have a great role in treating various types of cancers (1). In this study compounds 10d-I were docked into the VEGFR-2 binding site to explore their binding mode and possible interactions. 3CP9 is the pdb file (2) used in docking process, it was downloaded, refined, water molecules were removed, hydrogen atoms were added and the active binding site was detected using MOE program. The synthesized compounds were docked into the active site, the obtained docking scores are presented in table (7). Compounds $10 \mathrm{~d}$ and $10 \mathrm{e}$ showed lower score energy than the other derivatives with VEGFR-2. The p-hydroxyl group in compound 10d formed a hydrogen bond with Thr916 amino acid and the phenyl moiety showed an arene-cation interaction with Lys868 (Fig. 7). Compound 10e formed arene-cation interaction with Lys868 amino acid through its phenyl moiety (Fig. 8).
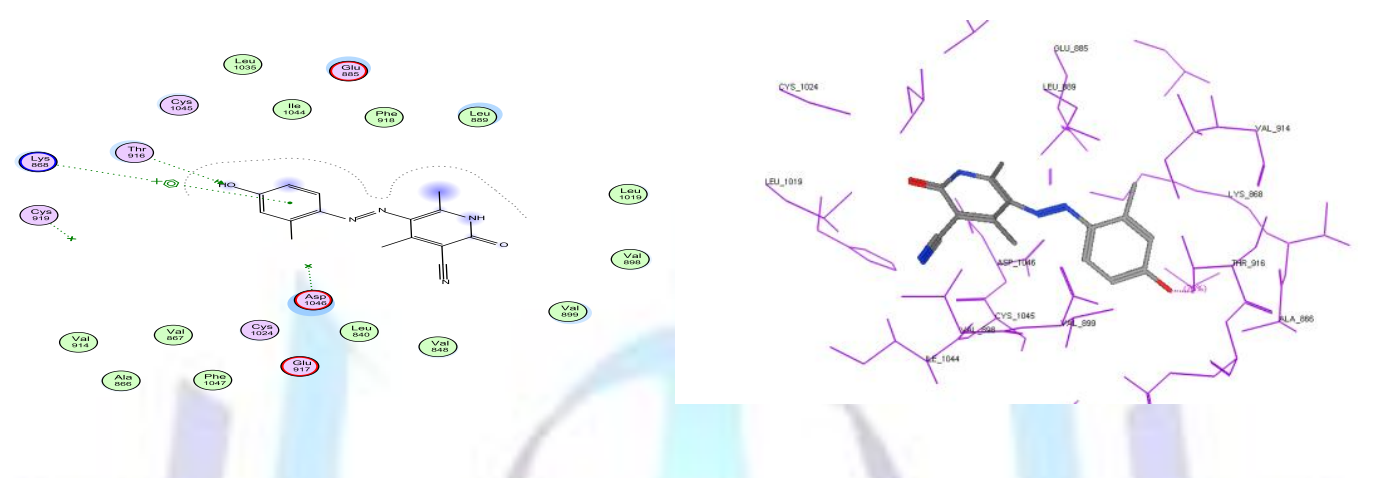

Figure (7): 2D and 3D interactions of comp. 10d with VEGFR2 binding site.

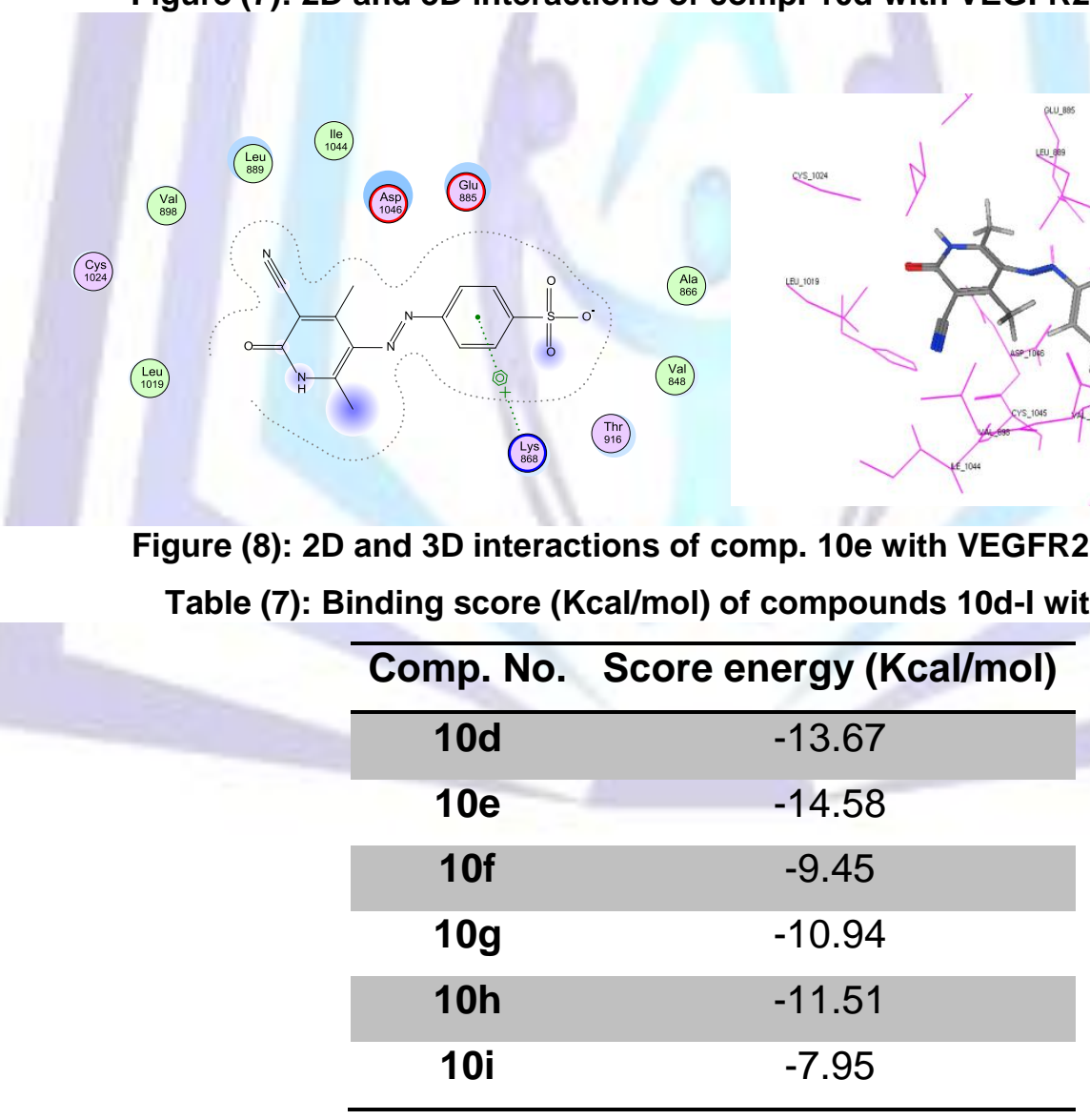

\section{Methodology}

\section{A- Chemistry}

All melting points were measured on a Gallenkamp melting point apparatus. The infrared spectra were recorded in potassium bromide discs on a Pye Unicam SP 3-300 and Shimadzu FT IR 8101 PC infrared spectrophotometers. The 
NMR spectra were recorded on a Varian Mercury VXR-300 NMR spectrometer $\left({ }^{1} \mathrm{H} \mathrm{NMR}(300 \mathrm{MHz})\right.$ and ${ }^{13} \mathrm{C}$ NMR $(75.46$ $\mathrm{MHz})$ ) were run in deuterated chloroform $\left(\mathrm{CDCl}_{3}\right)$ or dimethyl sulfoxide (DMSO- $\left.d_{6}\right)$. Chemical shifts were related to that of the solvent. Mass spectra were recorded on a Shimadzu GCMS-QP1000 EX mass spectrometer at $70 \mathrm{eV}$. Elemental analyses were carried out at the Micro-analytical Centre of Cairo University, Giza, Egypt and recorded on Elementar-Vario EL automatic analyzer. The Microwave reactor was used in this work is the CEM mars machine. CEM has several vessel types that are designed for their ovens: (1) Closed-system vessels including the HP-500 (500 psig material design pressure and $260{ }^{\circ} \mathrm{C}$ ), pictured below, have liners are composed of PFA and are ideal for many types of samples. HP-500 Plus vessels are ideal for routine digestion applications. Process up to 14 high-pressure vessels per run with temperatures up to $260^{\circ} \mathrm{C}$ or pressures up to 500 psi.

A number of safeguards have been incorporated in the MARS 5 system to eliminate the possibility of an explosive high pressure material failure. Each reaction vessel fits within a microwave-transparent sleeve made of Kevlar, and each vessel-sleeve assembly gets clamped within a carriage or 'support module' with 5 foot-pounds of torque applied to the clamping bolt. A plastic membrane pressure rupture disc that fits between the exhaust port in the vessel lid and the threaded blue cap (shown in figure 1, and 2) ensures the digestion takes place under completely closed conditions at lower pressures. The blue cap has a small hole drilled in it. Should pressures exceed what is safe for the particular vessel the membrane will rupture, exhausting gas through the port in the vessel lid and the cap and into the oven, which exhausts into a fume hood. The microwave oven also has a rupture pressure sensor that stops the power to the microwave if it detects a sudden pressure change.

\section{Microwave method}

\section{Synthesis of 3-cyano-4,6-disubstituted-2-pyridones 9(a-c) and 3-cyano-4,6- disubstituted-5-arylazo-2-pyridones 10 (d-i)}

To a mixture of cyanoacetamide (6) (100 mmole) in silica gel $(5 \mathrm{~g})$ was added 1,3-dicarbonyl compound (4) (100 mmol) and equivalent amount of potassium hydroxide. The mixture was grinded well in a mortar and then was charged in a HP. 500 Plus process vessel. The vessel was capped properly and irradiated by microwaves under pressurized conditions $\left(17.2 \mathrm{bar}, 220^{\circ} \mathrm{C}\right)$ for certain time (see table 2$)$. After irradiation the reaction mixture was cooled and ethyl acetate/DMF mixture was added then sonication of the solution for one hour to extract the reaction product was done. Filtration of the mixture in a centered glass and the solvent was evaporated in vacuo gave solid was recrystallized from EtOH/DMF to afford (9), The reaction was indicated by TLC

\section{Conventional method (Method B):}

A mixture of cyanothioacetamide (6) (10 mmol), propane-1,3-dione derivatives (4) or 2-arylhydrazono-1,3diphenylpropane-1,3-diones $(5)(10 \mathrm{mmol})$ will be suspended in ethanol $(30 \mathrm{ml})$ containing potassium ethoxide $(0.68 \mathrm{~g}, 10$ $\mathrm{mmol})$. The mixture will be refluxed for long time, and then will be allowed to stand overnight. The resultant precipitate will be filtered and crystallized from the appropriate solvent to give the solid products as potassium salts (9) and (10). The potassium salt will be dissolved in water at $80^{\circ} \mathrm{C}$, filtered and neutralized with dilute hydrochloric acid (1M). The resulting solid product will be collected by filtration and washed with distilled water to remove sodium chloride. The product will be dried prior to crystallization from EtOH-DMF to afford the products (9) and (10).

Table (9) Comparison between microwave method and conventional method in synthesis of $(10 d-i)$

\begin{tabular}{ccccc}
\hline $\begin{array}{c}\text { Compound } \\
\text { number }\end{array}$ & \multicolumn{2}{c}{ Microwave } & \multicolumn{2}{c}{ Conventional } \\
\cline { 2 - 5 } & $\begin{array}{c}\text { Reaction time } \\
\text { (min.) }\end{array}$ & Yield & $\begin{array}{c}\text { Reaction time } \\
\text { (hrs) }\end{array}$ & yield \\
\hline $10 \mathrm{~d}$ & 4 & 90 & 7 & 71 \\
$10 \mathrm{e}$ & 3 & 94 & 7 & 75 \\
$10 \mathrm{f}$ & 3 & 89 & 6 & 63 \\
$10 \mathrm{~g}$ & 4 & 95 & 7 & 72 \\
$10 \mathrm{~h}$ & 4 & 97 & 7 & 78 \\
$10 \mathrm{i}$ & 3 & 93 & 6 & 67 \\
\hline
\end{tabular}


<smiles>Cc1[nH]c(=O)c(C#N)c(C)c1[N+](=O)[O-]</smiles>

Figure (6)

3-Cyano-4,6 dimethyl-5arylazopyridone $10 \mathrm{~d}-\mathrm{i}$

Table (10) The Spectral 1H NMR data of the synthesized compounds

\begin{tabular}{|c|c|}
\hline $\begin{array}{l}\text { Compound } \\
\text { number }\end{array}$ & Spectral1H NMR data \\
\hline $9 a$ & $\delta 2.2\left(\mathrm{~s}, 3 \mathrm{H}, \mathrm{CH}_{3}\right), 2.3\left(\mathrm{~s}, 3 \mathrm{H}, \mathrm{CH}_{3}\right), 6.28(\mathrm{~s}, 1 \mathrm{H}, \mathrm{Ar}-\mathrm{H})$ \\
\hline $9 b$ & $\begin{array}{c}\delta \delta 2.3(\mathrm{~s}, 3 \mathrm{H}, \mathrm{CH} 3), 6(\mathrm{~s}, 1 \mathrm{H}, \mathrm{N}-\mathrm{H}), 6.5(\mathrm{~s}, 1 \mathrm{H}, \mathrm{Ar}-\mathrm{H}), 7.6- \\
7.9(\mathrm{~m}, 5 \mathrm{H}, \mathrm{Ar}-\mathrm{H})\end{array}$ \\
\hline $9 c$ & $\begin{array}{c}\delta 6.5(\mathrm{~s}, 1 \mathrm{H}), 6.8-7.1(\mathrm{~m}, 5 \mathrm{H}, \mathrm{Ar}-\mathrm{H}), 7.4(\mathrm{~s}, \mathrm{~N}-\mathrm{H}) \\
\text { 7.5(d,1H,thiophene-H), } 7.7(\mathrm{~s}, 1 \mathrm{H} \text {,thiophene- } \mathrm{H}) \text {, } \\
7.8(\mathrm{~d}, 1 \mathrm{H} \text {,thiophene-H) }\end{array}$ \\
\hline $10 d$ & $\begin{array}{c}\delta 2.43\left(\mathrm{~s}, 3 \mathrm{H}, \mathrm{CH}_{3}\right), 2.55\left(\mathrm{~s}, 3 \mathrm{H}, \mathrm{CH}_{3}\right), 2.81\left(\mathrm{~s}, 3 \mathrm{H}, \mathrm{CH}_{3}\right), 4.81(\mathrm{~s}, \\
1 \mathrm{H}, \mathrm{OH}), 7.28-7.91(\mathrm{~m}, 3 \mathrm{H}, \mathrm{Ar}-\mathrm{H})\end{array}$ \\
\hline $10 e$ & $\delta 2.45\left(\mathrm{~s}, 3 \mathrm{H}, \mathrm{CH}_{3}\right), 2.57(\mathrm{~s} .3 \mathrm{H}, \mathrm{CH} 3), 7.11-7.81(\mathrm{~m}, 4 \mathrm{H}, \mathrm{Ar}-\mathrm{H})$ \\
\hline $10 f$ & $\begin{array}{c}\delta 2.47\left(\mathrm{~s}, 3 \mathrm{H}, \mathrm{CH}_{3}\right), 2.52\left(\mathrm{~s}, 3 \mathrm{H}, \mathrm{CH}_{3}\right), 7.30\left(\mathrm{~s}, 2 \mathrm{H}, \mathrm{NH}_{2}\right), 7.45- \\
8.06(\mathrm{~m}, 4 \mathrm{H}, \mathrm{Ar}-\mathrm{H})\end{array}$ \\
\hline $10 \mathrm{~g}$ & $\begin{array}{c}\delta 2.47\left(\mathrm{~s}, 3 \mathrm{H}, \mathrm{CH}_{3}\right), 2.57\left(\mathrm{~s}, 3 \mathrm{H}, \mathrm{CH}_{3}\right), 3.65\left(\mathrm{~s}, 3 \mathrm{H}, \mathrm{OCH}_{3}\right), \\
\left.\text { 3.81(s,3H, } \mathrm{OCH}_{3}\right), 3.86\left(\mathrm{~s}, 3 \mathrm{H}, \mathrm{OCH}_{3}\right), 6.94-7.11(\mathrm{~m}, 2 \mathrm{H}, \mathrm{Ar}-\mathrm{H})\end{array}$ \\
\hline $10 \mathrm{~h}$ & $\begin{array}{c}\delta 2.4\left(\mathrm{~s}, 3 \mathrm{H}, \mathrm{CH}_{3}\right), 2.48\left(\mathrm{~s} 3 \mathrm{H}, \mathrm{CH}_{3}\right), 3.63\left(\mathrm{~s}, 3 \mathrm{H}, \mathrm{OCH}_{3}\right) \\
3.78\left(\mathrm{~s}, 3 \mathrm{H}, \mathrm{OCH}_{3}\right), 6.93-7.23(\mathrm{~m}, 3 \mathrm{H}, \mathrm{Ar}-\mathrm{H})\end{array}$ \\
\hline $10 i$ & $\begin{array}{c}\delta 2.48\left(\mathrm{~s}, 3 \mathrm{H}, \mathrm{CH}_{3}\right), 2.57\left(\mathrm{~s}, 3 \mathrm{H}, \mathrm{CH}_{3}\right), 7.01\left(\mathrm{~s}, 2 \mathrm{H}, \mathrm{NH}_{2}\right), 6.91- \\
7.81(\mathrm{~m}, 4 \mathrm{H}, \mathrm{Ar}-\mathrm{H})\end{array}$ \\
\hline
\end{tabular}

\section{B- Biology}

\section{Material and methods}

\section{Anticancer activity}

\section{A- Cell culture}

The cells were obtained from Egyptian Holding Company for Biological Products \& Vaccines (VACSERA), Giza, Egypt and then maintained in the tissue culture unit .The cells were grown in RBMI-1640 medium, supplemented with $10 \%$ heat 
inactivated FBS, 50 units $/ \mathrm{mL}$ of penicillin and $50 \mathrm{mg} / \mathrm{mL}$ of streptomycin and maintained at ${ }^{23}$ in a humidified atmosphere containing $5 \% \mathrm{CO}_{2}$. The cells were maintained as monolayer culture by serial sub-culturing. Cell culture reagents were obtained from Lonza (Basel, Switzerland). The anticancer activity of the rested compounds was evaluated against MCF-7 cells (Breast cancer), HEPG-2 cells (Liver cancer).

\section{B- The sulforhodamine B (SRB) cytotoxicity assay}

Cytotoxicity was determined using the sulforhodamine B(SRB) assay method as previously described by Skehan et al. ${ }^{24}$ Exponentially growing cells were collected using 0.25\% Trypsin-EDTA and seeded in 96-well plates at 1000-2000 cells/well in RBMI-1640 supplemented medium. After $24 \mathrm{~h}$, cells were incubated for $72 \mathrm{~h}$ with various concentrations of the tested compounds. Following $72 \mathrm{~h}$ treatments, the cells would be fixed with $10 \%$ trichloroacetic acid for $1 \mathrm{~h}$ at $4{ }^{\circ} \mathrm{C}$. Wells were stained for 10 minutes at room temperature with $0.4 \%$ SRBC (Sulphorhodamine B) dissolved in $1 \%$ acetic acid. The plates were air dried for $24 \mathrm{~h}$ and the dye was solubilized with Tris-HCl for $5 \mathrm{~min}$ on a shaker at $1600 \mathrm{rpm}$. The optical density (OD) of each well was measured spectrophotometrically at $564 \mathrm{~nm}$ with an ELISA microplate reader (ChroMate-4300, FL, USA). The IC50 values were calculated according to the equation for Boltzman sigmoidal concentration response curve using the nonlinear regression fitting models (Graph Pad, Prism Version 5)

\section{C- Molecular Docking}

Molecular docking studies were performed using Molecular Operating Environment software 10.2008 (MOE) provided with chemical computing group, Canada. Validation process was performed after downloading the 3CP9 file by removing and redocking of the co-crystalized ligand into the VEGFR-2 binding site. 2D structures of the synthesized compounds were converted to 3D by MOE program, protonated, energy minimized using Merck Molecular force field (MMff 94x), saved as a data base file and docked into 3CP9 active site with a root mean standard deviation (RMDS) $=1.1027$. Docking scores are represented in table 10,2D and 3D interactions for the best docked compounds are presented in fig. 7 and fig. 8 .

\section{References}

1- Zhiliang LV, Yikaizhang, Mingfeng Zhang and others, "Design and synthesis of novel 2-hydroxy group substituted 2-pyridone derivatives as anticancer", European Journal of Medicinal Chemistry, 67(2013)447-453

2- E.A.abdelmotaal, M.S.A. EIGaby and M.A.salem, "Design, Synthesis and anticancer activity of new 3-cyano$2(1 \mathrm{H})$-pyridone and 3-cyanopyridine-2-(1H)-thione Derivatives, Oriental journal of chemistry, 2015, 31, (2), 875884.

3- Aleksandar marinkovic, Dusan mijin, jelena mirkovic, veselin maslak and C.Oliver kappe, journal of the Serbian chemical socity, 79(7), 759-765 (2014).

4- Dusan Z. miljin, jelena mirkovic, Aleksandar marinkovic, Danijela V. brkovic, Association of the Chemical Engineers of Serbia, 68(1), 1-14.

5- G.Johs, pyridines and their benzo derivatives: synthesis In: Boulton A,A Mckillop(Ed) comprehensive heterocyclic chemistry, pegamon press oxford 1984, p.395

6- Guareschi-Thorpe, Name reactions (A collection of detailed mechanisms and synthetic applications),Springer, 2009, p 270

7- Marcus Baumann* and lan R. Baxendale, "An overview of the synthetic routes to the best selling drugs containing 6-membered heterocycles", Beilstein J. Org. Chem. 2013, 9, 2265-2319

8- Taliani, S.; Bingliang Fang, Development of Synthetic Lethality Anticancer Therapeutics J. Med. Chem., Just Accepted Publication Date (Web): June 3, 2014

9- Maria Ruden, Neelu Puri "Novel anticancer therapeutics targeting telomerase Cancer Treatment" Reviews, Volume 39, Issue 5, August 2013, Pages 444-456

10- Nesnow, S.; Miyazaki, T.; Kawaja, T.; Meyer, B., "Pyridine nucleosides related to 5-fluorouracil and thymine" J. Med. Chem. 1973, 16, 524-528.

11- Imai, K. I.; Nohara, A.; Honjo, "Studies on A-Norsteroids. V. "Reaction of Steroidal Diosphenols with Manganese Dioxide" M., Chem. Pharm. Bull. 1966, 14, 1377-1381

12- Onodera, K.; Hirano, S. F., "Syntheses of O-Glycosides, Glycosylamines and Purine Nucleosides by Fusion Reaction in the Presence of Polyphosphoric Acid or Ethyl Polyphosphate as New catalyst" Agr. Biol. Chem., 1964, 28, 173-178.

13- Strauss, C. R. Aust. J. Chem., 1999, 52, 83.

14- Larhed, M.; Moberg, C.; Hallberg, A. Acc. Chem. Res., 2002, 35, 717.

15- Strauss, C. R. Application of Microwaves for Environmentally Benign Organic Chemistry. In Handbook of Green Chemistry and Technology; J. Clark, D. Macquarrie, Eds.; Blackwell Science Ltd: Oxford, 2002, pp 397-415.

16- Gedye, R.; Smith, F.; Westaway, K.; Ali, H.; Baldisera, L.; Laberge, L.; Rousell, J. Tetrahedron Lett., 1986, 27, 279.

17- Strauss, C. R. ; Trainor, R. W. Aust. J. Chem., 1995, 48, 1665.

18- Caddick, S. Tetrahedron, 1995, 51, 10403. 
19- Gabriel, C. ; Gabriel, S. ; Grant, E. H. ; Halstead, B. S. J. ; Mingos, D. M. P. Chem. Soc. Rev., 1998, $27,213$.

20- Elander, N. ; Jones, J. R.; Lu, S. Y.; Stone-Elander, S. Chem. Soc. Rev., 2000, 29, 239.

21- Lidstrom, P. ; Tierney, J. ; Wathey, B. ; Westman, J. Tetrahedron, 2001, 57, 9225.

22- Loupy, A. Microwaves in Organic Synthesis; Wiley-VCH: Weinheim 2002

23- Skhen, P.; Storeng, R.; Scudiero, D.; Monks, A.; McMahon, J.; Vistica, D.;Warren, J. T.; Bokesch, H.; Kenney, S.; Oyd, M. R. J. Nat. Cancer Inst. 1990, 82, 1107-1112.

24- Liebowitz, L. D.; Ashbee, H. R.; Evans, E. G. V.; Chong, Y.; Mallatova, N.;Zaidi, M.; Gibbs, M. Diagn. Microbiol. Infect. Dis. 2002, 4, 27-33.

25- El-Said MS1, El-Gazzar MG, Al-Dosari MS, Ghorab MM. Synthesis, anticancer activity and radiosensitizing evaluation of some new 2-pyridone derivatives. Arzneimittelforschung. 2012 Mar;62(3):149-56. doi: 10.1055/s0031-1299695. Epub 2012 Jan 23.

26- Lv Z1, Zhang Y, Zhang M, Chen H, Sun Z, Geng D, Niu C, Li K. Design and synthesis of novel 2'-hydroxy group substituted 2-pyridone derivatives as anticancer agents. Eur J Med Chem. 2013 Sep; 67:447-53. doi: 10.1016/j.ejmech.2013.06.046. Epub 2013 Jul 1

27- Saleh AM1, Aljada A, El-Abadelah MM, Taha MO, Sabri SS, Zahra JA, Aziz MA .The anticancer activity of the substituted pyridone-annelated isoindigo (5'-Cl) involves G0/G1 cell cycle arrest and inactivation of CDKs in the promyelocytic leukemia cell line HL-60. Cell Physiol Biochem. 2015; 35(5):1943-57. doi: 10.1159/000374003. Epub 2015 Mar 27.

28- Hu, E., Tasker, A., White, R.D., Kunz, R.K., Human, J., Chen, N., Burli, R., Hungate, R., Novak, P., Itano, A., Zhang, X., Yu, V., Nguyen, Y., Tudor, Y., Plant, M., Flynn, S., Xu, Y., Meagher, K.L., Whittington, D.A., Ng, G.Y. Discovery of Aryl Aminoquinazoline Pyridones as Potent, Selective, and Orally Efficacious Inhibitors of Receptor Tyrosine Kinase c-Kit. (2008) J.Med.Chem. 51: 3065-3068.

29- http://www.rcsb.org/pdb/explore/explore.do?structureld=3CP9 